\title{
RPTSS 2018
}

\section{International Conference on Research Paradigsm} Transformation in Social Sciences

\section{FORMATION OF SOCIALLY RESPONSIBLE RELATIONS SYSTEM AS CONDITION OF GROWTH IN WELL-BEING}

\author{
T. Yakimova (a)*, T. Artcer (b) \\ *Corresponding author
}

(a) Tomsk Polytechnic University, Lenin Avenue, 30, Tomsk, 634050, Russia, ostray@ yandex.ru, +73822606482

(b) Tomsk Polytechnic University, Lenin Avenue, 30, Tomsk, 634050, Russia, tv.arzer@gmail.com, +73822606482

\begin{abstract}
The article addresses problems of the subject matter and the key components of well-being among citizens. Here, well-being is considered a multiple-factor construct that represents a complex correlation between cultural, social, psychological, physical, economic, and spiritual factors. The article expands on the concept of socially responsible relations, the analysis of which makes it possible to explore the growth conditions of well-being more thoroughly. The article researches the social responsibility of the state, businesses, and society. It provides approaches to the measurement of social responsibility through continual human well-being. Social responsibility of the state is viewed through a social policy; the heart of this must be the guaranteeing of human rights to a standard of well-being and social protection in a given society. Social responsibility of the businesses through the implementation of social programs of internal and external orientation. Social responsibility of civil society is considered in the context of the activities of local self-government, public organizations, and citizens themselves. " Attention is given to the fact that the main responsibility for the results of socio-economic development, for the social well-being of its citizens is the state, as it organizes and implements the system in society and implements the principles of social integration and responsibility.
\end{abstract}

C 2018 Published by Future Academy www.FutureAcademy.org.UK

Keywords: Well-being, social, state, business, civil society. 


\section{Introduction}

The crisis of the welfare state, which is increasingly debated and written about in Russian and foreign periodicals, has justified serious reforms in the public sector and a shift in the focus of social protection establishments. A breakthrough idea was presented in the World Bank's Strategy for the field of social security and labor 2012-2020. Among the new functions of social protection, there are the following: 1) prevention of decreases in welfare under the conditions of abrupt changes in income and expenditure; 2) provision of better quality opportunities, sources, and jobs; 3) protection from impoverishment and disastrous loss of human capital assets.

In order to reflect the aforementioned trends, social science pundits have begun using the term "wellbeing", meaning the "continual prosperity" of man and society. This concept includes a wide range of objective and subjective evaluations of their own "continual" well-being made by people at different stages in life, including active working practice and well-being at an "advanced age" (Nekhoda, 2014).

\section{Problem Statement}

Well-being is a complex correlation of cultural, social, psychological, physical, economic, and spiritual factors. The well-being of a modern person is largely connected with opportunities to fulfill their needs, interests and self-realization opportunities in social, psychological, emotional, and informational fields. In general, well-being can be defined as a synthetic category, which includes such standard categories as standards of living, the quality of life, and lifestyle.

The authors of the "Well-being: The Five Essential Elements" book, Tom Rath and Jim Harter, put emphasis on the following areas of life as elements of well-being:

1. professional well-being (career, vocation, profession, or work);

2. physical well-being (good health);

3. social welfare (the importance of the immediate environment and social relations);

4. financial well-being (financial security, satisfaction with one's own standard of living);

5. well-being in the living environment (security, one's own contribution to the development of society).

At that, as the authors point out, achievements in one area cannot compensate for failure in another since we do not obtain everything from life without having achieved success in all five areas (Rath, \& Harter, 2010).

The achievement of well-being is inextricably connected with certain conditions, among which subjective and objective conditions can be highlighted. Subjective conditions include the desire of a person to satisfy one's needs, activity aimed at the fulfillment of one's capabilities and a certain potential (Kosmina \& Kosmin, 2014).

Objective conditions are related to the activity of the whole society, state policy, and the activity of different institutions and organizations. The socially responsible relation system plays an important role in this aspect. This system reveals itself in mutual social responsibility between state, businesses, and society for the results of social and economic development and the well-being of citizens (Sahoo, Chakravarty, Shubh, \& Singh., 2018). 
In practice, there are different ways of interaction and participation in the social and economic development of state, businesses, and society. First, social responsibility may be distributed in different proportions among subjects in a given society. And the more diverse the subjects of social responsibility in the society are and the larger their number is, the more social responsibilities are implemented quantitatively and qualitatively in this society. Second, the process of social responsibility implementation can develop various forms of relations between subjects of the society, among which the most common forms are the following: a) parity interactions (parallel, non-intersecting and not interfering with each other); b) partnership (complementarity); c) administration-subordination, domination-dependence; g) mutual stimulation of activity (Yakimova, 2012).

Specific forms, methods, ways of social responsibility implementation are different for subjects of social responsibility, as determined by the peculiarity of the functioning of each of them. The scale and the level of social responsibility, as well as mechanisms of its distribution among individual subjects, are defined by the normative system and the set of values operating in a particular society, which highlights the problem of determining optimal borders between the state, businesses, and society, and their ways of interaction in the process of implementing cumulative social responsibility (Barysheva, Artcer \& Casati., 2015). This problem is particularly relevant for modern Russia in virtue of the establishment of a new socially responsible system of relations.

\subsection{Social responsibility of state}

The social responsibility of the state reveals itself in social policy pursued by the state, which at the core should ensure human rights to well-being and social security in a given society. At that, as the experience of developed countries demonstrates, the social responsibility of the state reveals itself not only and not so much in the ability to distribute social benefits and support the social area, as in the ability to provide the conditions necessary for economic growth, for unlimited activities of individuals able to create goods and take care of themselves and their close ones.

The development of effective social policies is one of the most important tasks of Russian officials in modern conditions. Not only the living conditions of ordinary people depend on how this challenge is addressed, but also prospects for social and economic development of the country as well as national security.

It is suggested that four main functions should be outlined in determining the optimal type of social policy for Russia: ensuring social and political stability; help to the poor; ensuring the competitiveness of the country in the international arena in the globalized world by means of its human capital assets; ensuring the integration of society, its internal solidarity and cohesion.

To implement each of the functions requires different types of resources in different volumes and, to a large extent, different techniques of their use. For example, if the dominant function of social policy is to ensure stability, then resources are primarily directed to assist those population strata that are able to conduct protest actions. If the second function prevails, then the targeting of social care is increased. When they say that in today's world, social policy has long ago turned into a powerful tool to improve the quality of the human capital assets of the country, and ultimately to ensure its competitiveness in the international arena, investments in human capital assets become a priority. 
In recent years, budget system expenditures on the social sector have made more than a half of the overall budget expenses. Only over the last four years, they have grown 1.5 times in absolute terms, and in terms of the GDP share - from $18 \%$ to $21 \%$. (Federal State Statistics Service, 2016). The level of social protection is growing. At that, it is higher in Russia than in countries with comparable labor performance levels and per capita income. Thus, the emphasis is placed on the implementation of the second function of social policy listed above. At the same time, dissatisfaction among the population about the current state of affairs remains.

The Russian Academy of Sciences' data indicate that the most relevant aim of social policy that also complies with ideas of Russian citizens about social justice is to enhance the quality of the human capital asset of the country. Research has shown that the ideals of a conservative model of a social welfare state with reasonable social differentiation, an active role of state in everything that is related to the equality of chances and state guarantees of the satisfaction of minimum basic needs as the basis of views about social justice are close to the views of Russian population. In many respects, it is such a state that is able to provide conditions for the continual well-being of its citizens.

Today, the development of continual well-being in Russian economy is hindered by such problems as difficulties for university and college graduates in job placement, low wages, shadow economy, and relatively low social payments (Gasanov \& Zhironkin, 2014). In fact, social well-being can only be applied to the working-age Russian population with a stable income. Upon reaching advanced age and retirement, being provided with material benefits in Russia is greatly reduced.

\subsection{Social responsibility of Russian businesses and civil society actors}

Corporations often portray themselves as socially responsible members of society. These actions extend to, but are not limited to, the community where the firm operates; the environment; and the firm's treatment of employees, suppliers, and customers. The last few decades have seen a surge in corporate social responsibility (CSR). In 2014, U.S. and U.K. firms in the Fortune Global 500 spent $\$ 15.2$ billion on CSR. Investors increasingly appear to value CSR. According to a 2010 report on the trend in socially responsible investing, $\$ 3.07$ trillion of the professionally managed U.S. assets was tied to socially responsible investing (Jha \& Cox, 2015).

The social responsibility of businesses is a new phenomenon in the Russian economy. In general terms, it is a self-restriction of free enterprises in order to improve the social climate within the enterprise, create favorable conditions for attracting investments and motivating employees, and a growth in labor productivity. In these terms, it is common practice to distinguish between internal (enterprise staff-oriented, and including investments in human capital assets) and external (outside of an enterprise and local community-oriented) social responsibility. At that, corporate social responsibility is not only a management technology, pursuing purely market goals and results, but also an indicator of social activity, social functions, companies and should be aimed at continual human (employee) well-being in the organization (Karpova, Ardashkin, \& Kabanova, 2015). It should also facilitate the development of a social environment inside the organization and outside it, the development and maintenance of social bonds and social relations.

Therefore, when evaluating corporate social responsibility, it is important to take into account the contribution of business to the well-being of an employee and the continual well-being of the local 
community and society as a whole. An evaluation of well-being takes into account social responsibility at both macro and micro levels.

Social responsibility at the macro level assumes the participation of business in the implementation of social programs at the level of society. These programmes may relate to social investments in education, health care, security, environmental programs and environmental protection (Bhardwaj, Chatterjee, Dogerlioglu, \& Ozge, 2017).

Social responsibility at the micro level assumes participation of businesses (represented by owners and managers) in the implementation of social programs aimed at enterprise employees; implementation of corporate social policies by businesses (Barrena, Lopez, Pedro, \& Romero, 2015).

Both internal and external social programs are the most viable forms of the implementation of the social responsibility of businesses in Russia at the present stage. Costs associated with their implementation represent social investments and assume the achievement of a strategic social and economic effect by an enterprise. The prevalence of "internal" corporate social investments over "external" ones is a current trend in Russia: the ratio is approximately 60/40. This has been a sustainable, long-term trend. According to the Social investments fund, as for the amount of expenditures on the social area, the average index is $17 \%$ of the profits of companies, which is equal to about $1 \%$ of GDP (Anikeeva, 2012).

However, despite the favorable trends in the establishment and development of Russian socially responsible businesses, a number of factors that hinder the introduction of corporate social responsibility may be distinguished. Such factors include the following: the opacity of budgetary expenditures and corrupt officials, lack of a support policy from the authorities, lack of tax exemptions, the imperfection of the existing legislation, complexity of embezzlement prevention, as well as the weakness of the civil society and social partnership.

Businesses can only develop in a certain institutional environment formed by regulating rules, regulations, procedures, both in the economic and social area, which in turn opens the door for the institutionalization of entrepreneurship in the Russian society. In order to do this, businesses needs to interact with the organizational institutions of society, which are represented in Russia mainly by state government bodies. Thus, under modern conditions, the development of a socially responsible behavior in entrepreneurship is only possible with a purposeful support from the state and its active participation in the solution of social problems.

The state plays a significant role in the establishment and development of a civil society in Russia. The question of the development of a civil society in the context of our study is of special interest because it is the social area which has enough room to unleash its potential. The plurality of civil society subjects gives an opportunity to reduce the excessive social load on the state budget due to the ability of nongovernmental institutions to accumulate a large amount of funds and resources needed to solve social problems on the grassroots level. Internal civil society institutions are quite diverse. In this paper, "civil society institutions" refer to the following: the local government (in the non-governmental sense of this phenomenon); public organizations (non-profit organizations); individuals and their families.

The civil society in Russia is not yet a completed democratic project. In many ways, its development is hindered by the current state of the Russian society itself: sociocultural characteristics (paternalism, traditional character); the poor social structure with an underrepresented middle class; material insecurity 
of the majority of the population, the nature of power (tendency for monopolization, irremovability, bureaucratization).

Today, Russia needs time in order to form institutions of civil society in this country, and the state plays an important role in this process. A civil society, as well as businesses, requires a certain level of social responsibility of the state, in this case, manifesting itself in the creation of optimal conditions for the implementation of their fundamental vital interests, support for various forms of citizen participation in the discussion and solution of social, economic, and other issues (Yakimova, 2014).

At the same time, the social responsibility of Russian citizens is a necessary component of an effective civil culture, whose growth begins when multiple requirements are met, as the experience of developed countries shows. First, an improvement in the economic and social situation of the population in accordance with the growth in business activity. Second, wide participation of citizens in the ownership and administration of property. Third, the provision of a justified differentiation of income and consumption depending on the results of the activity, including entrepreneurial activity, of citizens. Fourth, the society has reached an optimum ratio level of expenditures on social purposes, which are taken on by the state, its citizens with their income, and entrepreneurs.

\section{Research Questions}

1. Study and analysis of the theoretical and scientific and practical literature on the subject of the study;

2. decomposition of the notion of "well-being" into its components;

3. consideration of problems of well-being from the perspective of the social responsibility of a state, businesses, and civil society.

\section{Purpose of the Study}

The purpose of the study is to analyze the system of socially responsible relations as a growth condition for the well-being of Russian citizens.

\section{Research Methods}

As main methods of research are systemic and interdisciplinary approaches, comparative, statistical and empirical analysis. The application of these methods allows us to analyze the essence of the object of study, to identify the relationship of the social sphere with other spheres of society.

The theoretical base for the study was the concept of the social state, monographic works and scientific articles of modern Russian and foreign authors, representing different areas of economic science. The empirical base of the research was the materials of official statistical institutions of the Russian Federation, information of special research of domestic and foreign scientists, materials of Russian and foreign periodical press.

\section{Findings}

The achievement of well-being is to a lrage extent linked to certain conditions, among which subjective and objective ones can be singled out. The achievement of an economic and social balance is an 
important point in the creation of favorable conditions of the growth in the well-being of citizens in modern society.

A socio-economic balance is reached under the conditions of a socially fair income distribution and through an economic mechanism that provides consumption growth that depends on performance growth, and as a result of an increase in the social responsibility for the outcomes of economic activity on the part of the government, business, civil society, and citizens themselves.

The formation of a rational model combining social responsibility of the state, business and civil society occurs in the absence of them as full subjects of social responsibility at the macro level..

\section{Conclusion}

The analysis of Russian reality from the perspective of social responsibility leads to the conclusion that today's Russia is in the situation of choice and establishment of the rational model of combining the social responsibility of the state, businesses, and civil society for the results of social and economic development and the social and economic well-being of Russian citizens. The main problem in this situation is the absence of full-fledged social responsibility subjects at the macro level. Therefore, the modern stage of institutional transformation in the social area can be defined as a formation stage of core social responsibility subjects - a welfare state, socially responsible businesses, and a civil society - conducted simultaneously with the institutionalization of the best forms of interaction between them. At that, the analysis shows that the state bears the primary responsibility for the results of social and economic development, for the social well-being of its citizens, as it is the state that organizes and implements the system itself in the society, and implements the principles of social integration and responsibility

\section{Acknowledgments}

This work was performed by the authors in collaboration with Tomsk Polytechnic University within the project in Evaluation and enhancement of social, economic and emotional wellbeing of older adults under Agreement No.14.Z50.31.0029 (19th of March, 2014).

\section{References}

Anikeeva, O. (2012). The social responsibility of an organization: functions, evaluation, and effectiveness: $P h D$ in Social Science thesis. Tyumen, Russia.

Barysheva, G., Artcer T., \& Casati F. (2015). State and Business Partnership as an Adaptation Instrument of Mechanical Engineering and Power Engineering Sector towards Global Climate Changes. Applied Mechanics and Materials, 770, 670-678.

Barrena, J., Lopez M., Pedro, F., \& Romero, M. (2015). Corporate social responsibility: Evolution through institutional and stakeholder perspectives European Journal of Management and Business Economics.25, 8-14. https://doi.org/10.1016/j.redee.2015.11.002.

Bhardwaj, P., Chatterjee, P., Dogerlioglu, D., \& Ozge, T. (2017). When and how is corporate social responsibility profitable? Journal of Business Research. 84, 206-219. https://doi.org/10.1016/j.jbusres.2017.11.026.

Gasanov, M., \& Zhironkin, S. (2014). Structural conditions of the neo-industrialization of the Russian economy. Theory and practice of social development, 10, 127-129.

Jha, A. \& Cox, J. (2015). Corporate social responsibility and social capital. Journal of Banking \& Finance, $60,252-270$. 
Karpova, A., Ardashkin I., \& Kabanova N. (2015). Organizational Culture in Focus of Measurements. Procedia-Social and Behavioral Sciences. 166, 246-253. https://doi.org/10.1016/j.sbspro.2014.12.519

Kosmina, E., \& Kosmin, A. (2014). Problems of ensuring constant human well-being. Bulletin of the Altai Academy of Economics and Law. Retrieved September 20, 2016, from http://journalaael.intelbi.ru/category $/ 2014$

Nekhoda, E. (2014). Corporate social responsibility: measurement problems. PFUR Bulletin, series Economy, 4, 93-103.

Rath, T., \& Harter, J. (2010). Wellbeing: The Five Essential Elements. New York, USA: Gallup press.

Sahoo S., Chakravarty K., Shubh S., \& Singh M. (2018). The problem of 'well' in the term 'Well-being' Asian Journal of Psychiatry.34, 61. https://doi.org/10.1016/j.ajp.2018.03.022.

The official website of the Federal State Statistics Service. (2016). Retrieved September 15, 2016, from http://www.gks.ru

Yakimova, T. (2014). The contribution of non-profit organizations to the well-being of citizens. Retrieved September 20, 2016, from http://www.science-education.ru/ru/issue/view?id=120

Yakimova, T. (2012). Institutional reforms in social services and economic development of Russia. Tomsk, Russia: RG Grafika 